Article

\title{
From Stakeholder Communication to Engagement for the Sustainable Development Goals (SDGs): A Case Study of LG Electronics
}

\author{
Hannah Jun ${ }^{1}\left(\mathbb{D}\right.$ and Minseok Kim ${ }^{2, *(D)}$ \\ 1 Graduate School of International Studies, Ewha Womans University, Seoul 03760, Korea; \\ hannahjun@ewha.ac.kr \\ 2 Sustainability Lab Inc., Seoul 06611, Korea \\ * Correspondence: kazakh@naver.com; Tel.: +82-10-5222-5533
}

Citation: Jun, H.; Kim, M. From Stakeholder Communication to Engagement for the Sustainable Development Goals (SDGs): A Case Study of LG Electronics. Sustainability 2021, 13, 8624. https://doi.org/ $10.3390 /$ su13158624

Academic Editor: Mohammad Nurunnabi

Received: 14 June 2021

Accepted: 24 July 2021

Published: 2 August 2021

Publisher's Note: MDPI stays neutral with regard to jurisdictional claims in published maps and institutional affiliations.

Copyright: (c) 2021 by the authors. Licensee MDPI, Basel, Switzerland. This article is an open access article distributed under the terms and conditions of the Creative Commons Attribution (CC BY) license (https:// creativecommons.org/licenses/by/ $4.0 /)$.

\begin{abstract}
While multi-stakeholder engagement is critical to achieving the Sustainable Development Goals (SDGs), there is less understanding in the literature about how the private sector can enhance such engagement at an institutional level. In this study, we examine the case of LG Electronics (LGE), one of South Korea's most sustainable firms. This case study highlights the key strategies that LGE employed in engaging stakeholders for the SDGs, with a focus on stakeholder scope and engagement over three phases: (1) stakeholder communication; (2) stakeholder involvement; and (3) stakeholder engagement. In addition, this paper emphasizes governance mechanisms that facilitated more effective stakeholder engagement, including the company's Corporate Sustainability Management (CSM) strategies, CSR Committee and Sustainability Management Council. These findings also highlight the usefulness of the common language provided by the SDGs in stakeholder engagement and provide practical implications for the private sector in contributing to the shared global agenda.
\end{abstract}

Keywords: LG Electronics; corporate sustainability management; stakeholder communication; stakeholder engagement; Sustainable Development Goals (SDGs)

\section{Introduction}

The Sustainable Development Goals (SDGs) represent an ambitious development agenda that is not only far-reaching and comprehensive in its aims, but unlike the preceding Millennium Development Goals (MDGs), highlights the centricity of partnerships in achieving the goals $[1,2]$. These partnerships are even more critical because of the SDGs' broad scope. For example, the 17 goals to be achieved by 2030 encompass traditional development objectives, such as no poverty (Goal 1), zero hunger (Goal 2) and quality education (Goal 4), but they also touch on issues that are relevant in both developing and more developed economies, such as industry, innovation and infrastructure (Goal 9) and sustainable cities and communities (Goal 11), as well as climate action (Goal 13) among others. While this means that successful multi-stakeholder engagement is critical to achieving the SDGs, there is less understanding in the literature about how the private sector can actually enhance multi-stakeholder engagement at an institutional level. This is complicated by the observation that the SDGs are seen as wicked processes that require cross-sector partnerships, the inclusion of various (and often conflicting) stakeholder perspectives and different types of partnerships to create systemic change [3]. Because of these complexities, we face an urgent need to better understand how firms can engage with stakeholders to achieve the SDGs and what obstacles need to be overcome.

With regard to case study research, we see ample studies on sustainability for firms in a developed economy context [4-7], with a focus on Europe and the United States. While there have been a growing number of studies from emerging [8-11] and developing economies [12], there is a relative paucity of research on stakeholder engagement for 
sustainability in Asian corporations despite their reach and visibility in the global supply chain. For countries such as South Korea, the academic literature has examined the role of national business systems and institutional characteristics [13] in understanding corporate social responsibility and has pointed to corporate concern for short-termism as opposed to longerterm sustainability [14]. However, while these studies have provided insight on what institutional pressures influence firm engagement in corporate social responsibility or sustainability domestically, there is little clarity on the actual processes and mechanisms of multi-stakeholder engagement at the firm level in light of globallyshared objectives, such as the SDGs. We argue that a better understanding of best practices and obstacles may be of particular salience in the Korean context given the country's economic dependence on chaebols, or family-owned and -managed conglomerates, as bringing them on board can generate significant gains in achieving a longerterm, shared global agenda.

To address these issues, we examine the evolution of multi-stakeholder engagement for the SDGs at LG Electronics, one of South Korea's largest consumer electronics firms and one that consistently ranks as one of the country's most sustainable companies [15]. For the study, we pay particular attention to stakeholder scope (how are key stakeholders defined?) and multi-stakeholder governance mechanisms (what are the processes of engaging stakeholders for the SDGs?) to generate useful insights for practitioners.

\section{Key Concepts and Methods}

When trying to understand multi-stakeholder engagement for the SDGs and the organizational challenges it presents, single-case studies may be helpful, as they can richly describe the existence of a phenomenon [16]. To highlight key processes and identify best practices for the case study, this paper first begins with a discussion on stakeholder theory. Then, this study analyzes multi-stakeholder engagement for the SDGs with a particular focus on (1) stakeholder scope and (2) the role of stakeholder governance.

\subsection{Stakeholder Theory and the SDGs}

In stakeholder theory, long-term value generation can be achieved not only by enhancing benefits to shareholders but by addressing the needs and expectations of a wide range of stakeholders, such as customers, employees, the supply chain, local communities, civil society and the government $[17,18]$. The challenge, however, is that these interests and expectations are not only complicated but they may also be conflicting [17-20]. For example, we can argue that the interests of shareholders, management and employees tend to be aligned with enhancing economic value (i.e., profit maximization), while local communities, governments, civil society and the public may focus on social value generation.

At the same time, stakeholder theory would argue that the key to generating future value and ensuring survival for the firm is to gain legitimacy from key stakeholders through core sustainability efforts $[18,21,22]$. As seen in previous research, stakeholder theory is helpful in explaining mutual interactions between corporate performance and disclosure, whereby greater social performance results in greater social disclosure, thus determining higher future social performance [23]. Additional studies further confirm that when it comes to integrated reports (IR) and global initiatives such as the SDGs, reports that include content on the SDGs are valuable to stakeholders who place importance on corporate attention to the SDGs and their inclusion in corporate strategy and respective business models [24]. Thus, while there may be a variety of stakeholders and a wide range of interests, there isagrowing consensus on the importance of both economic and social value generation by stakeholder groups, particularly as it relates to a firm's future sustainability. As such, a crucial task for firms is to create a framework that can blend stakeholder interests with a view to long-term, sustainable performance.

As mentioned in previous studies, a particularly helpful framework that can be used to communicate about a firm's sustainability efforts and performance is the SDGs. To achieve an ambitious agenda that addresses poverty alleviation, no hunger and pressing 
environmental issues, being able to harness the creativity and innovation unique to the private sector is critical. However, private sector participation for the SDGs remains limited and depends in large part on sustainability themes, national initiatives, firm size and corporate effort. In addition, as some argue that SDGs as addressed in sustainability reports are more symbolic than substantive in nature, sustainability reports may not constitute a reliable source for stakeholders such as investors when it comes to making decisions [25].

At the same time, it is clear that sustainability reports are valuable in tracking corporate efforts and progress toward the SDGs. Tools such as gravity analysis can be used to prioritize sustainability issues (and related stakeholder impacts), thus allowing for the implementation of a consistent firm-wide strategy, while international guidelines such as the GRI (Global Reporting Initiative) have been shown to be helpful in shaping practices within multinational corporations (MNCs) that align with the SDGs [26]. The SDGs also offer MNCs practical ways to implement sustainable business practices. In a study of 112 MNCs operating within the Association of Southeast Asian Nations, findings suggest that an MNC's headquarters have an impact on a firm's sustainable business practices [26].

With respect to corporate contributions to the SDGs, success may largely depend on addressing the keyword "nexus". In other words, the key will be to unlock how to generate shared benefits and reduce conflicts (particularly as it relates to addressing economic versus social impacts) with respect to SDG alignment and strategy implementation. When it comes to economic activities, corporate impacts are largely positive for SDG 8 (Decent Work and Economic Growth), SDG 9 (Industry, Innovation and Infrastructure) and also for goals related to overall human wellbeing (SDGs 2, 3, 4, 6, 7 and 11). At the same time, negative impacts are most apparent for those related to the broader ecosystem (e.g., Life Below Water (SDG 14) and Life on Land (SDG 15) and climate change (SDG 13) [27]. At the very least, stakeholder communication through channels such as sustainability reports provides an important avenue for disclosure on corporate impacts (both positive and negative) in light of the SDGs and may in turn serve as a mechanism to enhance legitimacy among stakeholders through this cycle of implementation, monitoring and ultimately disclosure.

\subsection{Defining Stakeholder Scope}

In stakeholder theory, addressing morals and values is a core and explicit feature of managing organizations [28]. As such, there has been active discussion in the literature about stakeholders [29-31] and engaging them toward shared, global objectives-most recently for the SDGs. It is clear that multi-stakeholder partnerships are needed [32] and efforts have been channeled to raise awareness to achieve the goals [33]. At the same time, one practical challenge is that given the broad definition of stakeholders, making clear distinctions between stakeholders is a complex task due to differences in salience [34] and the observation that stakeholders often belong to more than one group [35-37].

In recent research that explores the potential for multi-stakeholder partnerships for the SDGs, analysis has focused on country-level studies or multi-stakeholder initiatives [38] often directed under the auspices of international organizations. For example, Dodds [39] highlights the GAVI Alliance, the Global Portfolio Eradication Initiative, the Renewable Energy and Energy Efficiency Partnership, the Forest Stewardship Council and the UN Global Compact CEO Water Mandate for the analysis, while Mulholland et al. [33] examine communication and awareness activities in six countries as well as four major stakeholder groups. While business is identified as one of the key stakeholder groups, implications are largely limited to business associations, such as the World Business Council for Sustainable Development (WBCSD), and do not mention specific multi-stakeholder arrangements or best practices from the perspective of firms.

The country-level focus is also seen in the case of monitoring progress in implementing the SDGs [40]. However, while coherent and integrated plans implemented at the national level can certainly raise awareness and enhance coordination to achieve the SDGs, we can argue that the existence of such plans do not necessarily result in more successful partnerships (after all, for multinational corporations, the global scope of operations may 
make it more challenging to reflect diverse national development plans) and, conversely, that the absence of such a plan would result in sub-optimal performance. Even in the case of South Korea, we see that corporate attention to the SDGs came well before the establishment of the K-SDGs in 2018 and that the K-SDGs often do not have direct bearing on how Korean corporations set SDG priorities.

In addition to the lack of research from the perspective of firms on identifying stakeholders to achieve the SDGs, an additional consideration is that stakeholder scope may not be static. Based on these observations, in this paper, we seek to answer how stakeholders have been defined over time for one multinational corporation in such a way as to optimize multi-stakeholder engagement for the SDGs.

\subsection{Multi-Stakeholder Governance}

Governance concepts and theories emerged during the transition of government governance from management to entrepreneurship or in response to social change [41]. Jessop [42] defined governance as being "close to the concept of a horizontal autonomous organization among interdependent actors such as markets, countries, civil society", while Rhodes [43] found governance to represent "politics and diversity for governing intertwined organizations". International organizations such as the UNDP [44] have defined governance as "the exercise of political, economic and administrative authority in managing government affairs at all levels", while the Ministry of Environment of the Republic of Korea [45] defines it as "an alternative cooperative system or cooperative management system in which various subjects share their experiences and knowledge and form trust through the process of participation, solidarity and communication across the areas of the country, market and civil society, and seek directions for development together". In other words, governance encompasses stakeholder involvement in policy processes (both public and private) to not only seek solutions to pressing problems but to keep one another accountable.

Similar to the literature on defining stakeholders, research on multi-stakeholder engagement to achieve the SDGs has focused on governance at the national level. For example, Allen et al. [46] highlight the role of scenario frameworks in national development planning while Mulholland et al. [33] emphasize national initiatives to develop governance models that promote ownership of sustainable development. A more comprehensive study of early progress in achieving the SDGs [40] articulate nine steps in SDG implementation that span governance and coordination mechanisms, multi-stakeholder consultations, SDG mapping and alignment, prioritizing/adapting targets and indicators, mainstreaming existing/new strategies, SDG roadmap or action plan, assessing interlink ages, synergies and tradeoffs, policy evaluation and design and monitoring/reviewing arrangements (9). Although the framework was used to assess SDG guides and academic research as opposed to firm-level multi-stakeholder governance, core elements of the framework may prove helpful in better understanding the arrangement of stakeholder relationships for the SDGs between stakeholder groups and also within the firm (see Figure 1).

With this in mind, this paper aims to determine what governance mechanisms contribute to defining the scope of stakeholders and determining the methods of multistakeholder engagement through an in-depth case study.

\subsection{Data and Methods}

For this paper, we choose LG Electronics (hereafter, LGE) as the focus of analysis. According to Reputation Institute's 2019 Global RepTrak 100, the company ranked 48th in the world for corporate reputation and credibility-ahead of firms such as Samsung, Amazon and Apple [47]. Beyond overall corporate reputation, the choice of LGE as the focus of analysis is twofold. First, this is due to its standing as a sustainability leader in South Korea and, arguably, the global marketplace. Between 2014 and 2019, LGE was included five times in Corporate Knights Global 100 results, an index of the 100 most sustainable corporations in the world [48]. In the 2019 index, the company was one of just 
two Korean corporations that were included and the only Korean company included from the computer hardware industry. The company has also been included in the Dow Jones Sustainability Index (DJSI) World Index for eight consecutive years through to 2019 and was also selected for six consecutive years as the world's best firm in the home and leisure electronics category [49].

\begin{tabular}{|c|c|c|c|c|c|c|c|c|c|c|}
\hline \multirow[t]{2}{*}{ Publication } & \multirow[t]{2}{*}{ Details/Specific Tools } & \multicolumn{9}{|c|}{ Initial Steps in SDG Implementation } \\
\hline & & 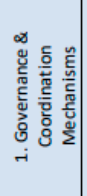 & 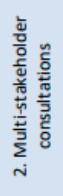 & 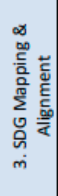 & 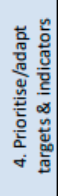 & 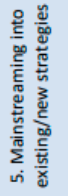 & 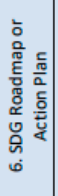 & 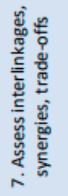 & 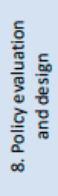 & 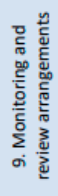 \\
\hline & modelling tools for SDGs & & & & & & & & & \\
\hline Collste et al. (2017) & $\begin{array}{l}\text { Scenario modelling of health- } \\
\text { education-energy nexus using } \\
\text { iSDGs model (Tanzania) }\end{array}$ & & & & $\checkmark$ & & $\checkmark$ & $\checkmark$ & $\checkmark$ & \\
\hline Singh et al. (2017) & $\begin{array}{l}\text { Framework for evaluating SDG } \\
\text { interactions; oceans nexus }\end{array}$ & & $\checkmark$ & & $\checkmark$ & & & $\checkmark$ & & \\
\hline Reyers et al. (2017) & $\begin{array}{l}\text { Essential variables for SDG } \\
\text { monitoring \& research agenda }\end{array}$ & & & & & & & $\checkmark$ & & $\checkmark$ \\
\hline Weitz et al. (2014) & $\begin{array}{c}\text { Approach for assessing WEF } \\
\text { interactions }\end{array}$ & & & & $\checkmark$ & & & $\checkmark$ & & \\
\hline Campagnolo et al. (2016) & $\begin{array}{c}\text { Global SDG indicator } \\
\text { assessment and index }\end{array}$ & & & & $\checkmark$ & & & & & $\checkmark$ \\
\hline $\begin{array}{l}\text { Organisation for Economic } \\
\text { Cooperation and } \\
\text { Development (2016b) }\end{array}$ & $\begin{array}{c}\text { SDG indicator-based } \\
\text { assessment and benchmarking } \\
\text { (OECD countries) }\end{array}$ & & & & $\checkmark$ & & & & & $\checkmark$ \\
\hline Allen et al. (2017b) & $\begin{array}{l}\text { SDG indicator-based } \\
\text { assessment and benchmarking } \\
\text { (regional) }\end{array}$ & & & & $\checkmark$ & & & $\checkmark$ & & $\checkmark$ \\
\hline
\end{tabular}

Figure 1. Nine steps in SDG implementation. Source: [40].

Second, among South Korean companies frequently included in global sustainability rankings and indexes, LGE is one of the few classified as a chaebol (or family-owned, family-managed conglomerate) or chaebol affiliate. While chaebols have been essential in South Korea's economic transformation over the past half-century through export-led industrialization [50,51], criticisms have included neglect on labor-related issues [52-54] and corruption stemming from poor corporate governance [55-57]. At the same time, the longevity of many chaebols to date suggests that they are wellpositioned (and have tremendous incentive) to cultivate a longerterm reputation of ethical business and sustainability. For example, SK chairman Chey Tae-won has insisted that SK's corporate investments should also create social value, having authored a book on social entrepreneurship and channeling financial resources to foster them [58]. Thus, through this study, we should be able to glean practical insights for firms in general and chaebols in particular when it comes to blending multi-stakeholder engagement and achieving the SDGs.

For the analysis, this paper heavily utilizes archival research, including corporate websites, sustainability reports and official press releases. In addition, one of the co-authors of this research was previously the head of LGE's corporate social responsibility team and is thus able to provide a unique perspective on the evolution of (1) stakeholder scope and engagement and (2) governance mechanisms to achieve the SDGs.

\section{From Stakeholder Communication to Engagement}

\subsection{Overview of LGE}

LGE is a global company with revenue totaling KRW 63.3 trillion (roughly USD 56.9 billion) in 2020 [59]. It has more than 100 business sites around the world and produces technologically innovative products and electronic goods, including televisions, mobile communication equipment, washing machines, refrigerators, car parts and solar panels. LGE launched its business in Korea in 1958 and produced various electronic goods, such as radio sets (model A501), telephones, TVs and air conditioners-becoming the first company 
to do so in Korea. It was also the first electronics firm to go public in 1973 and established the first private research institute in 1975, laying the foundation for the company to be grounded in transparent business management and technological innovation. In 1982, LGE established its first overseas production base in Huntsville, USA, accelerating its global reach and access to advanced technology. In 1989, however, the company went through a crisis stemming from a large scale labor dispute and demands to open up Korea's domestic market. Since then, LGE has overcome these crises through sweeping changes in management strategy and a new operating system based on a globalization strategy to establish local factories in Europe, China and Southeast Asia.

With regard to company identity, the company changed its name from Goldstar to LG Electronics in 1995 and restructured the corporate governance system into a holding company structure in 2003. A dedicated CSR (corporate social responsibility) department at LGE headquarters was established in 2008 in an effort to spearhead systematic implementation of the firm's Corporate Sustainability Management (CSM) strategies. In 2015, LGE officially announced its CSR vision of "cooperating toward a better life for all" to contribute to achieving the SDGs. In this sense, the firm aimed to not only become a market leader in terms of products and technology but to cement its position as a responsible firm in economic, social and environmental spheres to meet the growing needs of global stakeholders.

\subsection{Parties of Interest for LGE}

LGE is influenced by and influences a wide range of local and overseas stakeholders through its business activities. In order to understand stakeholder needs (which can then be reflected in business decisions), communication between management and stakeholders via appropriate channels is crucial. Given the centricity of stakeholder communication, the company has made efforts to better define stakeholder scope and tailor its communication approaches when it comes to coordinating efforts to achieve a global agenda.

\subsubsection{Stakeholder Selection}

Between the 1990s and 2006, LGE's priorities included identifying key stakeholders and improving communication. Although the company was already committed to communicating with global stakeholders on core aspects of its business activities, communication had become even more important within the framework of corporate social impacts and growing stakeholder demands. As effective stakeholder communication was increasingly seen as the best way to ensure mutual prosperity, the company began to focus on identifying and responding to stakeholders' views and needs. To do this, the company first distinguished between external and internal stakeholders and, based on this classification, designed a communication strategy for each target group.

For external stakeholders, targets and characteristics of external stakeholders include the following: (1) shareholders and investors; (2) customers; (3) business partners; (4) governments; (5) NGOs (non-governmental organizations) and civic groups; (6) communities; (7) industry peers; and (8) academia and opinion leaders.

Shareholders and investors: Increasingly, we have seen a surge in interest among investors regarding corporate sustainability. For example, global investment institutions such as Blackrock and Korea's National Pension Service (NPS) have been emphasizing environmental, social and governance practices when it comes to making investment decisions. As such, communication with shareholders and investors is very important. Primary communication channels include the general shareholders' meeting, performance presentations, IR (Investor relations) meetings, LGE's website, management and business reports, while stakeholders' key expectations include (1) disclosure and transparency; (2) increased investment value through efficient management; (3) corporate value improvement through sustainable activities; and (4) efforts to enhance ESG (environmental, social, governance) impacts. 
Customers: LGE communicates with customers through sales stores, service centers, surveys, exhibitions, websites, social networking services (SNS) and prosumer management activities. Customers primarily have expectations for (1) the provision of safe products and services; (2) fair marketing and accurate information disclosure; (3) privacy protection; and (4) customer protection.

Business partners: LGE communicates with business partners, such as suppliers, through its Global Supplier's Day, supplier portal system, satisfaction surveys, funds and programs for supporting suppliers. Business partners pay particular attention to fair trade issues and timely payment, with LGE also supporting suppliers' CSR activities.

Governments: As government policy and positioning play a significant role in business operations, the government constitutes an important stakeholder, especially as policies for business often differ by country and region. LGE communicates with central and/or local governments through public hearings, discussion meetings and seminars. The government has high expectations for the company, including legal compliance, tax regulations and cooperation with government policies.

NGOs and civic groups: Especially with the start of the SDGs, NGOs and civic groups have emerged as important stakeholders. With a growing number of companies declaring their support for the achievement of the SDGs, NGOs and civic groups have the opportunity to strictly monitor corporate pledges. In particular, advocacy-focused NGOs serve as a powerful watchdog for companies, as they monitor the veracity of SDG-related activities. LGE communicates with NGOs mainly through seminars, discussion meetings, community distribution activities and the corporate website, while expectations of the company include (1) environmental protection;(2) participating in and supporting tackling global social issues; (3) contributing to achieving the SDGs;(4) contributing to labor and human rights protection; and (5) bridging the digital divide.

Communities: As LGE conducts business in more than 100 countries, effective communication includes interacting with members of communities who come from diverse cultures and backgrounds. The company maintains close relationships through community care activities, sports sponsorships, discussion meetings and through the corporate website. Communities request the minimization of environmental impacts near facilities, respect for the culture and traditions of local communities, promotion of contributions to local communities and contributions to the local economy by hiring local employees to LGE.

Industry peers: LGE joined the RBA (Responsible Business Alliance, formerly EICC) in 2010 and works with the industry to create and comply with standards related to sustainable management and CSR. While industry peers also represent a source of business competition, they are also avid supporters of sustainable management and thus help contribute to the mainstreaming of sustainable management practices. As such, since 2013, LGE has included industrial peers in its main stakeholder pool to identify industry trends and collect opinions.

Academia and opinion leaders: As academic circles and related stakeholders can provide additional perspectives on management practices, LGE receives feedback on ways to improve sustainable management and often conducts joint research on specific issues.

When it comes to internal stakeholders, key stakeholder groups include (1) employees; (2) subsidiaries; and (3) LG group affiliates. Key targets and characteristics for each group are outlined as follows:

Employees: Executives and employees are important stakeholders and the company encourages voluntary participation by helping them understand and implement sustainable management practices. This includes regular training programs for executives and employees and incorporating sustainable management as a key agenda item in business meetings organized by top management.

Subsidiaries: While LGE's overseas subsidiaries were not originally included in the company's list of stakeholders, subsidiaries became increasingly important as it became clear that effective coordination with regard to laws, regulations and community needs related to sustainable management was needed to achieve the SDGs. 
LG group affiliates: As the LG Group is comprised of electronics, chemical and telecommunications companies, LGE includes LG Group affiliates among key internal stakeholders to create synergy for the group's CSR strategy and to enhance business synergy between each company.

\subsubsection{Changes in LGE's View on Stakeholder Management}

While LGE sets targets as defined in 3.2.1 for its main stakeholders and collects feedback on sustainable management activities, this paper also notes changes in perspectives on stakeholder management over time. Until 2006, LGE stakeholder management was described as "Stakeholder Communication". This period marked the introduction of stakeholder communication activities, and, as such, forming relationships with various stakeholders was the company's biggest priority. Core activities consisted of collecting opinions and needs from stakeholders.

Between 2006 and 2014, LGE's view on stakeholder management activities was defined in terms of "Stakeholder Involvement". This marked a period when stakeholder participation was further expanded from the previous notion of "Stakeholder Communication". In the previous stage, LGE recognized the importance of stakeholder management and focused on forming relationships, while in the "Stakeholder Involvement" stage, the company introduced stakeholder advisory meetings, listened to stakeholders' opinions more actively and began to receive acknowledgement that the company was interested in sustainable management activities and contributing to the then-Millennium Development Goals (MDGs).

Since 2015, LGE has been managing stakeholders from the perspective of "Stakeholder Engagement". Through to this point, LGE had expanded participation with stakeholders from "communication" to "involvement". However, the "engagement" phase marked a substantive shift in reflecting stakeholder needs, from the selection of goals for sustainable management and reflecting feedback on efforts to achieve those goals. Establishing priorities for LGE's sustainable management activities and matching this with respective SDGs also began during this stage of engagement. One of the biggest achievements in the stakeholder engagement phase was the declaration of LGE's Sustainability Commitments in 2017. Based on the economic, social and environmental issues that stakeholders consider important, LGE set mid- to long-term goals that can contribute to the achievement of the SDGs and included management's initiatives to implement them.

\subsubsection{Stakeholder Requirements Analysis}

LGE has made concerted efforts to reflect corporate sustainability issues raised by stakeholders in internal decision-making processes and systems. The company identifies corporate sustainability issues that are of interest to stakeholders based on feedback received through reader surveys in sustainability reports, media research analysis, interviews and surveys with expert groups and by deriving best practices and benchmarking sustainability reports of competitors and major global corporations. In addition, the company monitors and analyzes global sustainability management initiatives and evaluation systems, the company's vision and strategy, issues in the electronics industry and media exposure from a comprehensive perspective to identify important issues related to sustainability management. LGE also conducts surveys of internal and external experts to assess priorities and impacts of key issues.

Among these stakeholders' requirements, there was an opinion from NGOs in 2010 that LGE-as a major player in the global business landscape-should have keen interest in the MDGs. As a result of that engagement, LGE added "Contribute to Achieving UN Millennium Development Goals" to its social contribution framework and focused on activities that could contribute to the achievement of the MDGs. particularly in the areas of preventing environmental disease, promoting environmental sustainability and helping to eradicate poverty in development countries (see Figure 2). Since 2015 and the subsequent 
emphasis on SDGs by the government as well as by NGOs, LGE has been using the SDGs as primary indicators for sustainable management.

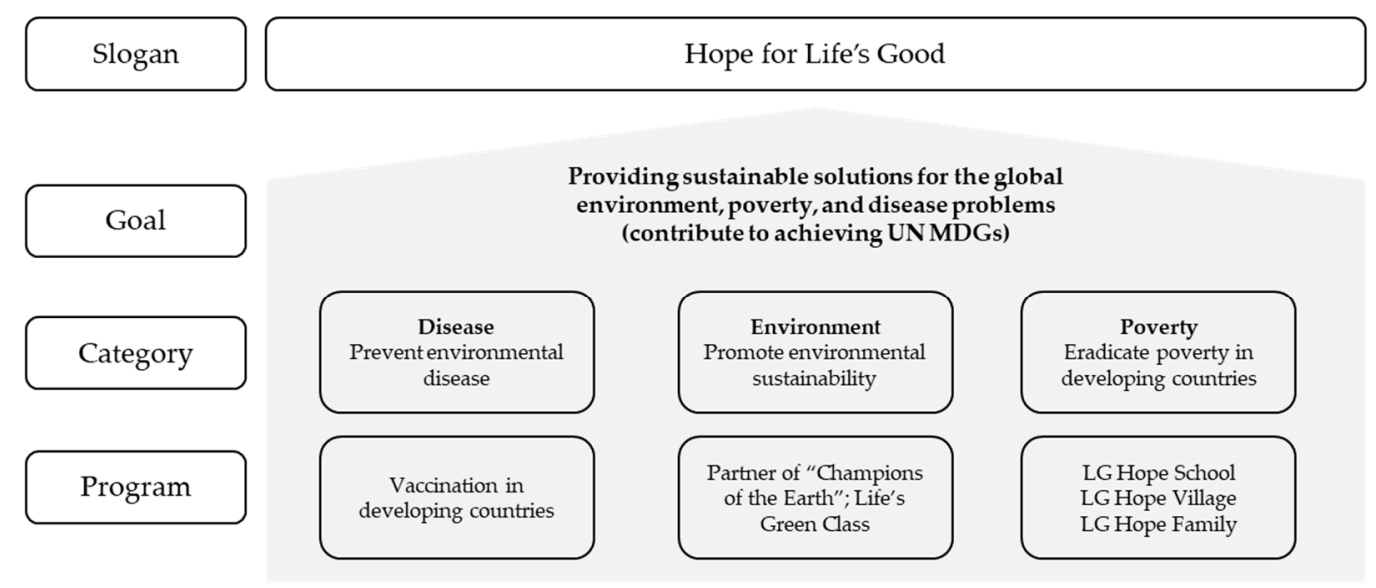

Figure 2. LGE's Social Contribution Framework (2010-2014). Source: LG Electronics Sustainability Report 2011-2012.

\subsection{LGE's Stakeholder Engagement Process}

LGE implements a systematic process to gather opinions from stakeholders. The company conducts a materiality assessment in-line with the principles of sustainability, materiality, stakeholder participation and completeness, which are also information disclosure principles of the Global Reporting Initiative (GRI) standards. To identify important sustainability management issues, LGE analyzes global sustainability management initiatives and evaluation systems, including the Dow Jones Sustainability Index (DJSI), The Financial Times Stock Exchange (FTSE) and the Responsible Business Alliance (RBA), the company's vision and strategy, issues in the electronics industry and media exposure. The company also conducts regular surveys of internal and external experts to assess the priorities and impact of key issues.

When it comes to the actual engagement process, the company first analyzes what issues would be of most interest to key stakeholders, as defined in Table 1. These sustainability management issues are deduced from a review of global sustainability management standards and initiatives, evaluation of system analysis and best practices in the industry and through a review of internal directions of the company's vision and business strategy. Stakeholders' requests and media interest are also taken into serious consideration.

Table 1. Changes in stakeholders over time ${ }^{1}$.

\begin{tabular}{cccccc}
\hline & Stakeholders & 2006 & 2007-2012 & 2013-2014 & 2015-Present \\
\hline \multirow{5}{*}{ External } & Shareholders/Investors & $\mathrm{O}$ & $\mathrm{O}$ & $\mathrm{O}$ & $\mathrm{O}$ \\
& Customers & $\mathrm{O}$ & $\mathrm{O}$ & $\mathrm{O}$ & $\mathrm{O}$ \\
& Business Partners & $\mathrm{O}$ & $\mathrm{O}$ & $\mathrm{O}$ & $\mathrm{O}$ \\
(Suppliers) & Governments & $\mathrm{O}$ & $\mathrm{O}$ & $\mathrm{O}$ & $\mathrm{O}$ \\
& NGOs/Civil Groups & $\mathrm{O}$ & $\mathrm{O}$ & $\mathrm{O}$ & $\mathrm{O}$ \\
& Communities & & $\mathrm{O}$ & $\mathrm{O}$ & $\mathrm{O}$ \\
& Industry Peers & & & $\mathrm{O}$ & $\mathrm{O}$ \\
& Academia/Opinion & & & $\mathrm{O}$ & $\mathrm{O}$ \\
& Leaders & & & $\mathrm{O}$ & $\mathrm{O}$ \\
\multirow{3}{*}{ Internal } & Employees & $\mathrm{O}$ & $\mathrm{O}$ & $\mathrm{O}$ & $\mathrm{O}$ \\
\hline
\end{tabular}

${ }^{1}$ Based on an analysis of company sustainability reports and data. 
Next, based on this list, the company prioritizes key issues based on surveys that aim to identify which areas LGE should focus on. The company quantifies the impact of these issues from four perspectives: (1) strategy;(2) finance;(3) management; and (4) reputation. Based on this materiality assessment of external and internal stakeholders, key priorities among the large pool of issues investigated are set.

Finally, items in need of improvement are targeted and time-tested by each department. These have been classified into three categories: (1) promotion of intelligent lifestyles; (2) realization of zero carbon and a circular economy; and (3) creation of a better society, in connection with LGE's mid- to long-term sustainability management goals. Elements included in reporting include the management approach, strategic direction, activities and achievements, goals and progress; the results of which are re-shared with stakeholders to complete the engagement process.

As mentioned earlier, LGE identified internal and external stakeholder groups, such as customers, suppliers, evaluation agencies and local communities. As an example of one method used to gather opinions from these stakeholders, LGE has operated stakeholder consultations since 2010. LGE conducts interviews and consultations with stakeholders to check the status and direction of LGE's sustainability management. Participants of these consultations include experts in various areas, such as human rights, the environment and the local community, as well as LGE managers related to these areas of business. Through these consultations, stakeholders and company representatives share their ideas on how to build a better future for the company. LGE also then reflects the opinions of stakeholders regarding sustainable growth in its management activities.

\subsection{LGE's Corporate Sustainability Management (CSM) System}

From early on, LGE has sought to create customer value based on the principle of respect-based management. A Corporate Sustainability Management (CSM) task force team was created at the end of 2005 to provide a systematic approach to sustainability management and build a foundation for company-wide sustainability activities. LGE also created a CSM forum with the CSM task force at its core, while also including all company divisions related to management strategy, human resources, social contribution, ethics, finance, corporate culture and the environment. The forum is responsible for promoting in-house understanding of the importance of CSM activities, with participants being able to share information on activities pursued by each business division, build stronger networks and help prepare the Sustainability Report among others (see Table 2).

Table 2. LGE's initial CSM direction.

\begin{tabular}{|c|c|c|}
\hline & Communication & Value \\
\hline \multirow[b]{2}{*}{ External } & Relationship & Market Leadership \\
\hline & $\begin{array}{l}\text { - } \quad \text { Strengthening communication } \\
\text { with stakeholders } \\
\text { - } \quad \text { Actively communicating on CSM } \\
\text { activities }\end{array}$ & $\begin{array}{l}\text { - } \quad \text { Expanding global leadership } \\
\text { Enhancing brand value and } \\
\text { leading the global electronics } \\
\text { industry }\end{array}$ \\
\hline & Integration & Risk Management \\
\hline Internal & $\begin{array}{ll}\text { - } & \text { Creating CSM system } \\
\text { - } & \text { Setting up internal system for } \\
& \text { sustainable management }\end{array}$ & $\begin{array}{ll}\text { - } & \text { Systematically managing risk } \\
\text { - } & \text { Managing non-financial risks } \\
\text { through a systematic approach }\end{array}$ \\
\hline
\end{tabular}

To spearhead a lean and more systematic approach to CSM adept at understanding and implementing global sustainability standards, LGE created a CSM office in 2007.Since then, the company's CSM activities have been overseen by the CSM office and are carried out in close cooperation among related departments. The emphasis has been on formulating CSM strategies and a roadmap for implementation, integrated management of non-financial risks and performance, building up internal competencies, brand management and marketing and linking CSM activities with stakeholder communication. 
Since 2009, LGE has also operated its CSR Committee (which is constituted by top executives, including the CEO) to brief executives on major CSR and CSM agendas and obtain top management decisions on related issues. In addition, LGE reports on CSR issues-buyer requests, risk assessment results and social contribution efforts-in management meetings for each business company, in which the company president and executives participate to raise management awareness on CSM issues and facilitate improvement efforts. LGE's working-level CSR Staff Council, which consists of CSR managers from company headquarters, business companies and overseas subsidiaries, is organized into three working-level groups that handle (1) stakeholder engagement;(2) social contribution; and (3) risk management issues, respectively. In addition to training CSR managers to build up core competencies, the council is entrusted with formulating specific action plans and improvement measures for each area and translating CSR objectives into actual performance initiatives.

\subsection{LGE and the Millennium Development Goals (MDGs)}

Prior to the launch of the Sustainable Development Goals in 2015, LGE began engagement in international initiatives in earnest in 2010 when the company announced its intention to contribute to the UN Millennium Development Goals. With the company having strengthened global social contributions since 2009 and with the focus of activities centering on disease, environment and poverty issues, LGE was asked by overseas stakeholders to join the effort to the MDGs. As a result, the company included MDGs within its Social Contribution Framework in 2010, and the MDGs had become important indicators in LGE's social contribution areas.

Of the eight MDGs, LGE focused its activities on MDG 1 (Poverty Eradication), MDG 2 (Education), MDG 6 (Disease Eradication), MDG 7 (Sustainability) and MDG 8 (Global Partnership) between 2010 and 2015. To achieve MDG 7 and MDG 8, LGE supported and became a strategic partner for international organizations such as the United Nations Environment Programme (UNEP), established partnerships with universities, operated the "Life's Green Class" program, and conducted environment and science education programs for teenagers. In order to achieve MDG 1, MDG 2 and MDG 7, the LG Hope Partnership was established with the United Nations World Food Programme (UN WFP). The partnership helped provide school meals in Ethiopia and Kenya to cultivate educational opportunities for children and programs to help local communities through rural development programs in Bangladesh and Cambodia. It also hosted a campaign to fight hunger with Médecins Sans Frontières (MSF) to support the production and screening of a documentary on the theme of hunger. Regarding MDG 6 and MDG 8, LGE sponsored vaccine research and development and vaccination for the purpose of preventing environmental diseases in less-developed countries with the International Vaccine Institute (IVI). In particular, LGE and IVI completed development of vaccines to prevent Ethiopian cholera disease and provided free vaccinations to residents.

\subsection{LGE and the Sustainable Development Goals (SDGs)}

Ahead of the start of UN SDGs in 2016, LGE established a new Social Distribution Framework that reflected the intent and purpose of the SDGs. The framework was based on a reexamination and reformulation of key principles that govern the company's social contribution efforts through intense discussions with key stakeholders and management. In line with these new guidelines, the company was committed to expanding the impact and range of contributions in addressing social issues, and, in the longer term, generating positive and enduring change in communities. Rather than having categories such as "disease", "environment" and "poverty", as utilized in the past, the goal of the new framework was framed within the broader objective of "working together to achieve SDGs". Based on that, a period of brainstorming of specific goals of what and how the company should achieve SDGs was set in motion. 
The subsequent vision for sustainability reflected the core belief that empathy in the company's mindset and consideration of its actions would contribute to building a better society. These principles, which have been embedded in the SDGs, were blended into LGE's three strategic directions for sustainability (see Figure 3). First, the company would commit to delivering differentiated value to those who need its products and technologies. In line with this, the company continues to develop and distribute products and technologies that help address social and environmental issues in communities. Second, the company would value stakeholder opinions and make every effort to engage and collaborate with stakeholders through diverse channels. This includes incorporating engagement outcomes into business operations. Third, every member of the organization would continuously explore ways in which the company can help those in need and build a better life together. This includes volunteering time and expertise to create a community where everyone feels respected and valued.

\section{Life's Good with LG}

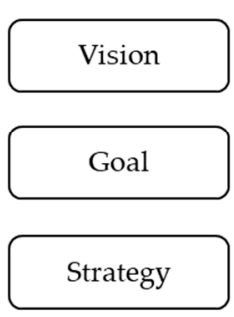

Cooperating toward a better life for all

Working together to achieve SDGs
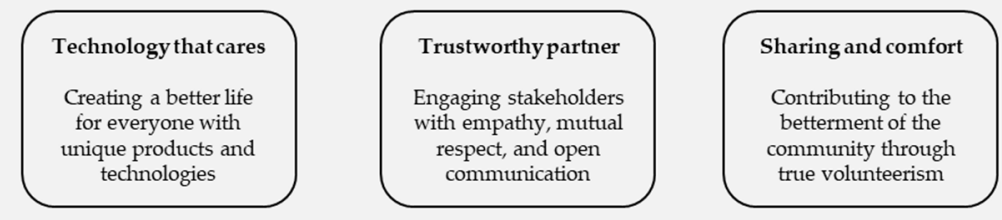

Figure 3. LGE's Social Contribution Framework from 2015. Source: LG Electronics Sustainability Report $2015-2016$.

Through careful study of the SDGs and associated targets, LGE has assessed the relevance of these goals and targets for its own sustainability initiatives while also taking into account overall management conditions, such as the nature and purpose of business operations and future opportunities and risks. The end result of this process was the identification of nine SDGs that have considerable relevance to LGE's goals, businesses and core competencies. The company has also prioritized these goals to strategize actions, with the company planning to focus on SDGs that are highly relevant to businesses and core competencies.

\section{Focus on Governance}

\subsection{LGE's Governance for the SDGs}

In LGE's case, the launch of the holding company system laid the groundwork for heightened transparency. The LG Group was able to put an end to cross-shareholding among affiliates, as the holding company was fully responsible for investments, and LGE was able to concentrate on increasing corporate value through its own operations. Importantly, the company successfully implemented a system of professional management, while its BOD-focused system has improved corporate transparency. Through these efforts, LGE set up a framework to strengthen business competitiveness at home and abroad, ultimately increasing shareholder and corporate value.

In terms of communication, one important initiative has been the constant development of communication channels, such as campaigns to raise public awareness about sustainability management. To ensure that stakeholders' expectations and demands are promptly reflected in the company's business activities, LGE has promoted the functions of the CSR Council and raised the top management's awareness on sustainability, thereby enhancing overall governance for sustainability management. 
In particular, the CSR Committee is at the core of LGE's CSM (see Figure 4). It regularly reports global trends and the company's strategic direction for sustainable management to the Board of Directors. Decisionmaking in key management meetings, including those at the executive level, takes into consideration the importance of sustainable management. An example of the most practical working group is the "Executive Council for Sustainability Management". The Executive Council tasks each functional department in the enterprise to take practical steps to achieve sustainable management and evaluates these results every year. LGE's CSM-related organizational chart (Figure 4) is shown as follows.

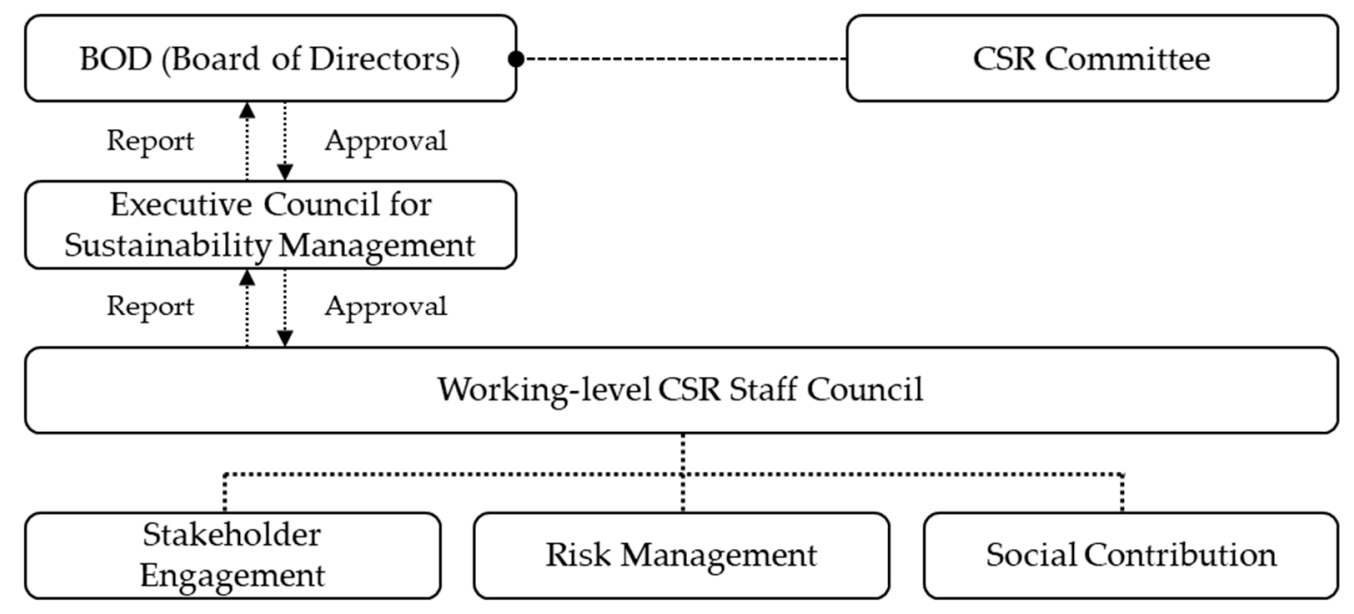

Figure 4. Organization chart for sustainability management. Source: LG Electronics Sustainability Report 2015-2016.

To pursue sustainable growth through stakeholder value creation, LGE established four strategic implementation tasks: (1) sustainability governance; (2) risk management; (3) stakeholder engagement; and (4) strategic social contribution.

In 2009, LGE created the CSR Committee, which is constituted by C-level officers, presidents of companies and regional representatives, and is chaired by the CEO. In 2010, a strategic decision-making process was carried out for activities including membership of the RBA (Responsible Business Alliance, former EICC) and announcement of the company's Global Labor Policy. Corporate sustainability plans were also being shared and discussed on a regular basis through the global CSR Council, which is constituted by CSR Committee members. LGE's participation in international initiatives includes its being a signatory of the UNGC (United Nations Global Compact) in 2009 and its membership in RBA. RBA was founded in 2004 by eight global electronic companies, including HP and IBM, with their declaration of the RBA Code to lead corporate social responsibility. Currently, over 150 companies worldwide (including LGE) have joined to pool efforts in resolving shared issues of the global electronics industry. Through its membership and involvement, LGE has reinforced its policy to respect the RBA Code in all of its Korean and overseas business sites. It has also published the Supplier Code of Conduct in 2010 to provide guidelines for suppliers to effectively fulfill their respective social responsibilities.

\subsection{Case of LGE's Governance}

\subsubsection{CSR Committee for the SDGs}

The CSR Committee is a subcommittee of the Executive Management Committee (constituted by top executives, including company presidents), which acts as the primary arm to brief executives on CSR and sustainability issues and secure an executive decisions on key issues. In addition, LGE reports CSR issues (i.e., recent CSR issues, customer requirements, risk assessment results and social contribution initiatives) in management meetings at each business company, which is led by the company president and attended by executives. These governance mechanisms have contributed to raising management 
awareness on CSR and sustainability issues and facilitate decisionmaking on action plans and solutions.

The CSR team participates in the CSR Committee to brief top management on emerging CSR risks and present cause-related marketing programs. This allows the company to take advantage of products and technologies to address local community issues to achieve both economic and social value. CSR was incorporated as part of the official duty of the Board of Directors, and the Committee briefs board members on important CSR issues to align social contribution initiatives and management direction. In 2016, the board was briefed on trends in CSR regulations and a new social contribution framework that reflected the SDGs. Since then, LGE has regularly reported on progress to achieve SDGs in the CSR Committee and has become the standard for the company's official sustainable management. This was encapsulated in LGE's Sustainability Commitments, which was reported to the CSR Committee in 2017.

\subsubsection{Sustainability Management Council}

After the CSR Committee confirms the direction and strategy of the company's sustainable management, it needs a channel for implementation. In order to implement these action plans, LGE established the Sustainability Management Council (Executive Council and Working-level CSR Staff Council), which is constituted by executives in charge of CSR and sustainability issues and working-level staff from the related departments (HR/Labor Management Team, Environmental Policy Team, Ethics Bureau and Shared Growth Bureau). Reviews on overall progress take place on a quarterly basis. With respect to the SDGs, this council sets tasks and targets to be executed in each functional department and measures results regularly.

The Sustainability Management Council convenes on an annual basis, while the Staff Council meets on a semiannual basis to review progress and performance. Through the council, LGE compiles improvement initiatives at the beginning of the year and develops corporate-level programs. At the Staff Council, LGE discusses and decides on stakeholder requirements that demand multi-departmental efforts (including those from customers), while delegating issues that require executive decisionmaking, such as system improvements, to the Executive Council convened in the second half of the calendar year.

\subsubsection{LGE's Social Contribution Initiatives and the SDGs}

LGE carries out social contribution activities in accordance with its social contribution strategy, which is set in consideration of the company's business characteristics, sustainable management policy and the SDGs. LGE's three strategic initiatives for social contribution are (1) "technology that cares", which solves social and environmental issues; (2) "building partnerships based on trust", which emphasizes communication with stakeholders; and (3) "sharing with others", in which employees participate. Through these efforts, social contribution activities have reflected the opinions of major stakeholders in-line with the SDGs. Through this engagement process (see Figure 5), five goals were identified as highly relevant for LGE. These include Good Health and Well-Being (SDG 3), Quality Education (SDG 4), Decent Work and Economic Growth (SDG 8), Industry, Innovation and Infrastructure (SDG 9) and Sustainable Cities and Communities (SDG 11).

\begin{tabular}{|c|c|c|c|c|}
\hline Step 1 & Step 2 & Step 3 & Step 4 & Step 5 \\
\hline $\begin{array}{l}\text { Set contributions } \\
\text { towards the } \\
\text { achievement of SDGs } \\
\text { as a major goal of our } \\
\text { social contribution } \\
\text { activities }\end{array}$ & $\begin{array}{l}\text { Analyze the } \\
\text { relationship between } \\
\text { the business } \\
\text { characteristics of LGE } \\
\text { and SDGs }\end{array}$ & $\begin{array}{l}\text { Set five SDGs } \\
(\text { SDGs } 3,4,8,9,11)\end{array}$ & $\begin{array}{l}\text { Select suitable } \\
\text { countries and regions } \\
\text { by analyzing their } \\
\text { relationships with } \\
\text { LGE }\end{array}$ & $\begin{array}{l}\text { Implement a social } \\
\text { contribution program } \\
\text { for community }\end{array}$ \\
\hline
\end{tabular}

Figure 5. Social contribution procedure reflecting SDGs. 


\section{Discussion}

\subsection{Importance of Stakeholder Engagement in Implementing the SDGs}

As corporate attention and contributions to the SDGs constitute a relatively new area of academic discussion, empirical studies remain limited [26] (van de Walls). At the same time, research has explored individual firms' interpretation of the SDGs [60,61], sustainable practices to achieve the SDGs [62] and sustainable investment in light of the SDGs [63]. Given the contributions of case studies, such as that by Fleming et al. [60] which helped uncover that SDG awareness was an important motivation for SDG engagement, this particular case study on LGE aimed to highlight the importance of stakeholder participation and specific mechanisms that encouraged stakeholder engagement in contributing to the SDGs.

LGE's initial interest in the UN MDGs was at the request of the UN agency and international NGOs. Due to the nature of the MDGs, government-level support was emphasized for poor and developing countries, which limited corporate participation and made it difficult to find a driving force for the promotion of the MDGs within the company. As a result, until 2015, the role of the corporation was to understand the concept of the MDGs at stakeholders' request and to engage in passive participation to achieve the MDGs in-line with initiatives by NGOs and local governments.

The SDGs, however, specifically emphasize the role and responsibilities of the private sector. Private business activity, investment and innovation are major drivers of productivity, including economic growth and job creation. This provides a unique engagement point for business participation, which ranges from micro enterprises and cooperatives to multinationals. LGE's case highlights the application of creativity and concrete action to solving sustainable development challenges. These actions also align well with core principles being championed by almost all businesses today, including the protection of labor rights, environmental and health standards in accordance with international standards and initiatives (including the UN Guiding Principles on Business and Human Rights, labor standards of the International Labour Organization and the Convention on the Rights of the Child, as well as the 2030 agenda for sustainable development).

Key stakeholders, such as the government, investors, customers and NGOs, are increasingly demanding active corporate participation to contribute to the SDGs, and effective stakeholder engagement can help companies pursue the goals most relevant to their business scope by linking core strategies with specific SDGs. The following Table 3 highlights major stakeholder needs in the SDGs era [64].

\subsection{LGE's Expectations for Stakeholders}

In an earlier section, we identified what stakeholders expect from companies-specifically for the case of LGE. However, what do companies expect from stakeholders? While it is difficult to answer this important question as stakeholder needs and interests vary, the SDGs serve as a common language to communicate with a wide range of stakeholders. In this respect, the language of the SDGs has allowed for clearer communication between LGE and its stakeholders on core issues. For example, the "Sustainability Commitment" set out by LGE in 2017 set detailed goals in economic, social and environmental subsets with clear linkages to SDGs. The company was able to communicate its activities and results on sustainable management using this framework, which allowed stakeholders to better understand and communicate more effectively with the company while working together to support the broader sustainability agenda. As such, a practical implication of this case study is that using the language of the SDGs through detailed plans that encompass economic, social and environmental issues allows for better two-way communication between the company and key stakeholders. 
Table 3. Needs of key stakeholders in the SDGs era.

\begin{tabular}{|c|c|}
\hline Stakeholder & Stakeholder Requests \\
\hline \multirow[b]{2}{*}{ Government } & Introduction and reform of policies and systems for SDGs. \\
\hline & $\begin{array}{l}\text { - Accelerating human rights and environmental regulations, including } \\
\text { supply chain. } \\
\text { - Supporting the involvement of capital markets and NGOs and urging the } \\
\text { disclosure of information. }\end{array}$ \\
\hline \multirow[b]{2}{*}{ Investors } & Require non-financial information related to ESG as a driver of long-term value. \\
\hline & $\begin{array}{l}\text { SDGs integration movement in the rule of disclosure of non-financial } \\
\text { information related to ESG. } \\
\text { - Communication with prior investment companies using SDGs as a } \\
\text { common language. }\end{array}$ \\
\hline \multirow[b]{2}{*}{ NGOs } & $\begin{array}{l}\text { Participation in companies that are deepening and diversifying with SDGs as } \\
\text { leverage. }\end{array}$ \\
\hline & $\begin{array}{l}\text { - Conduct a "name and shame" campaign for companies that have a } \\
\text { negative impact. } \\
\text { - Jointly advocate policies and link businesses to SDGs areas of interest. }\end{array}$ \\
\hline \multirow{2}{*}{ Customers } & $\begin{array}{l}\text { A growing number of consumers are making "belief-based" purchases, placing } \\
\text { importance on corporate attitudes toward social issues. }\end{array}$ \\
\hline & - $\quad$ This tendency is strong in those who know SDGs. \\
\hline
\end{tabular}

\subsection{Future Challenges}

At this point, it is unclear to what extent we will be able to achieve the 2030 agenda. An emphasis on economic development may hinder the social and (particularly) environmental goals encapsulated in the SDGs. As such, greater attention needs to be paid to creating a governance nexus that considers both the generation of positive economic benefits and the minimization of negative externalities [27]. For LGE's case, this would include managing the firm in a way that considers key SDGs and overarching implications on business operations as opposed to a fragmented view of the 17 goals.

Specifically, there is a need to foster experts who understand both the SDGs and core business activities in the enterprise. For companies, SDGs are not only implementable in aspects of social contribution but throughout all business activities within the firm's value chain. Cultivating a group of experts that can develop meaningful and feasible strategies to embed the values championed by the SDGs will accelerate the company's contribution to achieving the goals. Second, each department in the enterprise should identify factors that can contribute to the SDGs and establish clear targets and action plans to achieve them. This makes it possible to quantitatively measure an entity's contribution to the SDGs and confirm that SDGs are actually internalized within the business. Lastly, companies should regularly and transparently disclose its participation and efforts in achieving SDGs to internal and external stakeholders. As highlighted in this case study, participation in the SDGs began with engaging stakeholders. If this is the case, the entity needs to continue communicating with stakeholders about its level of interest in the SDGs, the activities it has supported and the results of its participation. By doing so, the company will not only enhance accountability, but this virtuous feedback loop will allow the firm to affirm stakeholders' expectations and reflect them in the company's strategic direction. Moreover, among the nine steps in SDG implementation, this study finds that the area that LG Electronics needs the most improvement in is (5) Mainstreaming into existing and new strategies. In other words, the SDGs should be included and considered in LG Electronics' business strategy. As emphasized earlier, governance is critical for the implementation of the SDGs in corporation. As such, LGE, whose governance has proven strong to date, should also consider the SDGs (and by extension societal and environmental considerations) in making business decisions. 


\section{Conclusions}

In this paper, we analyzed the complexities of multi-stakeholder engagement at LG Electronics in contributing to the Sustainable Development Goals (SDGs). Specifically, we focused on the evolution of stakeholder scope and multi-stakeholder governance for the study. As stakeholder scope and needs are not static, this case study traced the changing scope of stakeholders (both internal and external) for LGE and identified three key phases in stakeholder management: (1) stakeholder communication; (2) stakeholder involvement; and (3) stakeholder engagement. This analysis was further enhanced through an exploration of LGE's previous experience in reflecting the Millennium Development Goals (MDGs), which provided the foundation on which to engage more directly with the SDGs.

In terms of governance, while the launch of a holding company system provided the foundation for greater transparency, the development of communication channels both internally and with external stakeholders facilitated awarenessbuilding and coordination in addressing the SDGs within the company. This paper highlighted the importance of regular communication with executive management and the Board of Directors, particularly through mechanisms such as the CSR Committee and Sustainability Management Council. Lastly, social contributions were also aligned with specific SDGs to streamline the company's sustainability efforts.

On a final note, this case study acknowledged the practical usefulness of the SDGs in providing a common language for the private sector and key stakeholders to identify, implement and monitor contributions to globallyshared goals for development. While key challenges remain, such as cultivating expert practitioners in both the SDGs and the company's core business, matching key targets to each department and ensuring regular and transparent communication within the organization and with stakeholders, we believe this case study will provide those in the private sector with practical insights to better engage stakeholders to contribute to the SDGs and global initiatives going forward.

Author Contributions: Conceptualization, H.J. and M.K.; methodology, H.J.; validation, H.J. and M.K.; formal analysis, M.K.; investigation, H.J.; resources, M.K.; data curation, M.K.; writingoriginal draft preparation, H.J. and M.K.; writing-review and editing, H.J. and M.K.; visualization, H.J.; supervision, M.K.; project administration, H.J. All authors have read and agreed to the published version of the manuscript.

Funding: This research received no external funding.

Institutional Review Board Statement: Not applicable.

Informed Consent Statement: Not applicable.

Data Availability Statement: Not applicable.

Conflicts of Interest: The authors declare no conflict of interest.

\section{References}

1. Van Tulder, R. Business \& The Sustainable Development Goals: A Framework for Effective Corporate Involvement; Rotterdam School of Management, Erasmus University: Rotterdam, The Netherlands, 2018.

2. MacDonald, A.; Clarke, A.; Huang, L.; Roseland, M.; Seitanidi, M.M. Multi-stakeholder partnerships (SDG\# 17) as a means of achieving sustainable communities and cities (SDG\# 11). In Handbook of Sustainability Science and Research; Springer: Cham, Switzerland, 2018; pp. 193-209.

3. Van Tulder, R.; Keen, N. Capturing collaborative challenges: Designing complexity-sensitive theories of change for cross-sector partnership. J. Bus. Ethics 2018, 150, 315-332. [CrossRef]

4. Dhanda, K.K. Case study in the evolution of sustainability: Baxter International Inc. J. Bus. Ethics 2013, 112, 667-684. [CrossRef]

5. Gröschl, S.; Gabaldón, P.; Hahn, T. The co-evolution of leaders' cognitive complexity and corporate sustainability: The case of the CEO of Puma. J. Bus. Ethics 2019, 155, 741-762. [CrossRef]

6. Høgevold, N.; Svensson, G. A business sustainability model: A European case study. J. Bus. Ind. Mark. 2012, $27,142-151$. [CrossRef]

7. Matinaro, V.; Liu, Y. Towards increased innovativeness and sustainability through organizational culture: A case study of a Finnish construction business. J. Clean. Prod. 2017, 142, 3184-3193. [CrossRef] 
8. Anbarasan, P. Stakeholder engagement in sustainable enterprise: Evolving a conceptual framework, and a case study of ITC. Bus. Strategy Environ. 2018, 27, 282-299. [CrossRef]

9. Gopal, P.R.C.; Thakkar, J. Analysing critical success factors to implement sustainable supply chain practices in Indian automobile industry: A case study. Prod. Plan. Control 2016, 27, 1005-1018. [CrossRef]

10. Hatipoglu, B.; Alvarez, M.D.; Ertuna, B. Barriers to stakeholder involvement in the planning of sustainable tourism: The case of the Thrace Region in Turkey. J. Clean. Prod. 2016, 111, 306-317. [CrossRef]

11. Rathore, P.; Kota, S.; Chakrabarti, A. Sustainability through manufacturing in India: A case study on mobile handsets. J. Clean. Prod. 2011, 19, 1709-1722. [CrossRef]

12. Ng, S.I.; Chia, K.W.; Ho, J.A.; Ramachandran, S. Seeking tourism sustainability-A case study of Tioman Island, Malaysia. Tour. Manag. 2017, 58, 101-107. [CrossRef]

13. Lee, K.H.; Kim, C.H. Corporate social responsibility (CSR) practice and implementation within the institutional context: The case of the Republic of Korea. In Corporate Social Responsibility in Asia; Springer: Cham, Switzerland, 2014; pp. 65-82.

14. Kim, C.H.; Amaeshi, K.; Harris, S.; Suh, C.J. CSR and the national institutional context: The case of South Korea. J. Bus. Res. 2013, 66, 2581-2591. [CrossRef]

15. Kim, S.G. The study on the CSR-focused on LG Electronics. J. Dig. Conv. 2016, 14, 69-83. [CrossRef]

16. Siggelkow, N. Persuasion with case studies. Acad. Manag. J. 2007, 50, 20-24. [CrossRef]

17. Freeman, R.E. Strategic Management: A Stakeholder Approach; Pitman: Boston, MA, USA, 1984.

18. Clarkson, M.B.E. The Toronto conference: Reflections on stakeholder theory. Bus. Soc. 1994, 33, 82-131.

19. Alkhafaji, A.F. A Stakeholder Approach to Corporate Governance: Managing in a Dynamic Environment; Quorum Boo: New York, NY, USA, 1989.

20. Wood, D.J.; Jones, R.E. Stakeholder mismatching: A theoretical problem inempirical research on corporate social performance. Int. J. Organ. Anal. 1995, 3, 229-267. [CrossRef]

21. Donaldson, T.; Preston, L.E. The stakeholder theory of the corporation: Concepts, evidence, and implications. Acad. Manag. Rev. 1995, 20, 65-91. [CrossRef]

22. Ruef, M.; Scott, W.R. A multidimensional model of organizational legitimacy: Hospital survival in changing institutional environments. Adm. Sci. Q. 1998, 43, 877-904. [CrossRef]

23. Roberts, R.W. Determinants of corporate social responsibility disclosure: An application of stakeholder theory. Account. Organ. Soc. 1992, 17, 595-612. [CrossRef]

24. Manes-Rossi, F.; Nicolò, G.; Tudor, A.T.; Zanellato, G. Drivers of integrated reporting by state-owned enterprises in Europe: A longitudinal analysis. Meditari Account. Res. 2020. [CrossRef]

25. Van der Waal, J.W.; Thijssens, T. Corporate involvement in sustainable development goals: Exploring the territory. J. Clean. Prod. 2020, 252, 119625. [CrossRef]

26. Topple, C.; Donovan, J.D.; Masli, E.K.; Borgert, T. Corporate sustainability assessments: MNE engagement with sustainable development and the SDGs. Transnatl. Corp. 2017, 24, 61-71. [CrossRef]

27. Van Zanten, J.A.; Van Tulder, R. Towards nexus-based governance: Defining interactions between economic activities and Sustainable Development Goals (SDGs). Int. J. Sustain. Dev. World Ecol. 2020, 28, 210-226. [CrossRef]

28. Phillips, R.; Freeman, R.E.; Wicks, A.C. What stakeholder theory is not. Bus. Ethics Q. 2003, 13, 479-502. [CrossRef]

29. Freeman, R.E.; Philips, R.A. Stakeholder Theory: A Libertarian Defense. Bus. Ethics Q. 2002, 12, 331-349. [CrossRef]

30. Savage, G.T.; Nix, T.W.; Whitehead, C.J.; Blair, J.D. Strategies for assessing and managing organizational stakeholders. Acad. Manag. 1991, 5, 61-75. [CrossRef]

31. Bryson, J.M. What to do when stakeholders matter: Stakeholder identification and analysis techniques. Public Manag. Rev. 2004,6, 21-53. [CrossRef]

32. Haywood, L.K.; Funke, N.; Audouin, M.; Musvoto, C.; Nahman, A. The Sustainable Development Goals in South Africa: Investigating the need for multi-stakeholder partnerships. Dev. S. Afr. 2019, 36, 555-569. [CrossRef]

33. Mulholland, E.; Bernardo, A.; Berger, G. Communication and awareness raising in the implementation of the 2030 Agenda and the SDGs: Activities and challenges. ESDN Q. Rep. 2017, 44, 1-49.

34. Mitchell, R.K.; Agle, B.R.; Wood, D.J. Toward a theory of stakeholder identification and salience: Defining the principle of who and what really counts. Acad. Manag. Rev. 1997, 22, 853-886. [CrossRef]

35. Crane, A.; Livesey, S. Are you talking to me? Stakeholder communication and the risks and rewards of dialogue. In Unfolding Stakeholder Thinking 2; Greenleaf Publishing: Sheffield, UK, 2003; pp. 39-52.

36. Winn, M.I. Building stakeholder theory with a decision modelling methodology. Bus. Soc. 2001, 40, 133-166. [CrossRef]

37. Gao, S.S.; Zhang, J.J. A comparative study of stakeholder engagement approaches in social auditing. Perspect Corp Citizsh 2001, 239, 239-255.

38. Fowler, A.; Biekart, K. Multi-stakeholder initiatives for Sustainable Development Goals: The importance of interlocutors. Public Adm. Dev. 2017, 37, 81-93. [CrossRef]

39. Dodds, F. Multi-Stakeholder Partnerships: Making Them Work for the Post-2015 Development Agenda. Global Research Institute. Available online: www.un.org/en/ecosoc/newfunct/pdf15/2015partnerships_background_note.Pdf (accessed on 4 June 2020).

40. Allen, C.; Metternicht, G.; Wiedmann, T. Initial progress in implementing the Sustainable Development Goals (SDGs): A review of evidence from countries. Sustain. Sci. 2018, 13, 1453-1467. [CrossRef] 
41. Choi, J.; Kim, J. A Study on Social Entrepreneurship. Korean J. Local Gov. Studies 2014, 18, 33-56.

42. Jessop, B. Governance failure. In The New Politics of British Local Governance; Macmillan: Basingstoke, UK, 2000.

43. Rhodes, R. The governance narrative: Key findings and lessons from the ESRC's Whitehall Programme. Public Adm. 2000, 78, 345-363. [CrossRef]

44. UNDP. Participatory Evaluation in Programmes Involving Governance Decentralization. In Management Development and Governance Division; Revised 22; UNDP: New York, NY, USA, 1996.

45. The Ministry of Environment of the Republic of Korea. A Study on the Construction of Environmental Governance for Sustainable Regional Development. Available online: http://me.go.kr/home/web/policy_data/read.do?pagerOffset=4860\&maxPageItems= 10\&maxIndexPages $=10 \&$ searchKey=\&searchValue=\&menuId=10259\&orgCd=\&condition.orderSeqId=6099\&condition.rnSeq= 4939\&condition. deleteYn=N\&seq=1528 (accessed on 23 September 2020).

46. Allen, C.; Metternicht, G.; Wiedmann, T. An iterative framework for national scenario modelling for the Sustainable Development Goals (SDGs). Sustain. Dev. 2017, 25, 372-385. [CrossRef]

47. Yonhap. LG's Global Reputation Ranking Surpasses Samsung, Amazon, Apple: Report. Available online: https://en.yna.co.kr/ view / AEN20190310000200320 (accessed on 23 September 2020).

48. Corporate Knights. Global 100 Data History. Available online: https://www.corporateknights.com/reports/global-100/ (accessed on 23 September 2020).

49. The Investor. S. Korean Companies Expand Presence on Dow Jones Indices. Available online: http://www.theinvestor.co.kr/ view.php?ud=20190915000192 (accessed on 23 September 2020).

50. Kim, E.M. Big Business, Strong State: Collusion and Conflict in South Korean Development, 1960-1990; SUNY Press: Albany, NY, USA, 1997.

51. Lee, S.M.; Yoo, S.; Lee, T.M. Korean chaebols: Corporate values and strategies. Organ. Dyn. 1991, 19, 36-50. [CrossRef]

52. Chang, K.S. Compressed modernity and its discontents: South Korean society in transition. Econ. Soc. 1999, $28,30-55$.

53. Jang, S.H. Continuing suicide among laborers in Korea. Labor Hist. 2004, 45, 271-297. [CrossRef]

54. Kwon, S.H.; O'Donnell, M. Repression and struggle: The state, the chaebol and independent trade unions in South Korea. J. Ind. Relat. 1999, 41, 272-294. [CrossRef]

55. Albrecht, C.; Turnbull, C.; Zhang, Y.; Skousen, C. The relationship between South Korean chaebols and fraud. Manag. Res. Rev. 2010, 33, 257-268. [CrossRef]

56. Campbell, T.L., II; Keys, P.Y. Corporate governance in South Korea: The chaebol experience. J. Corp. Financ. $2002,8,373-391$. [CrossRef]

57. The Economist. Korea Discount Minority Report: Corporate Governance Explains South Korea's Low Stockmarket Ratings. Available online: https:/ / www.economist.com/finance-and-economics/2012/02/11/minority-report (accessed on 15 December 2020).

58. Forbes. This Billionaire's ‘Terrible Purchase’ Just Made $\$ 14$ Billion in Profits, and Now He’s Ready for More. Available online: https:/ / www.forbes.com/sites/gracechung/2019/03/13/armed-with-cash-from-chipmaker-sk-hynix-korean-giantspends-billions-on-global-shopping-spree/\#3aa9b61b57d3 (accessed on 15 December 2020).

59. LG Electronics. Financial Information. Available online: https://www.lg.com/global/investor-relations-financial-info (accessed on 17 January 2021).

60. Fleming, A.; Wise, R.M.; Hansen, H.; Sams, L. The Sustainable Development Goals: A case study. Mar. Policy 2017, 86, 94-103. [CrossRef]

61. Pedersen, C.S. The UN Sustainable Development Goals (SDGs) are a great gift to business! Procedia CIRP 2018, 69, 21-24. [CrossRef]

62. Bebbington, J.; Unerman, J. Achieving the United Nations Sustainable Development Goals: An enabling role for accounting research. Account. Audit. Account. J. 2017, 31, 2-24. [CrossRef]

63. Schramade, W. Investing in the UN Sustainable Development Goals: Opportunitiesfor companies and investors. J. Appl. Corp. Financ. 2017, 29, 87-99. [CrossRef]

64. Deloitte Consulting. Sustainable Development Goals; Jinsungbooks: Seoul, Korea, 2020. 